\title{
SELECTED PROBLEMS OF TRANSPORT IN PORT TOWNS - TRI-CITY AS AN EXAMPLE
}

\author{
Marcin Budzyński \\ Dawid Ryś \\ Wojciech Kustra \\ Gdansk University of Technology, Poland
}

\begin{abstract}
Port towns are strategic places from the point of view of transport systems. They form integration junctions for various transport branches, apart from the traditional - road and railway ones, also for water (sea) transport which is active there. Moreover, air transport comes also into consideration, whose efficient functioning must be connected with good accessibility, that concerns sea transport as well. Efficient and safe servicing the ports is crucial for their functioning. Problems associated with the overloading of lorries, which leads to degradation of road surface structure , observed in Gdynia, are discussed as an example in this paper. Problems of road traffic safety (RTS) are presented in this paper on the example of Gdańsk. The two issues: the road traffic safety and road surface degradation constitute only some transport problems of port towns, but they are very important, from the point of view of their specificity, for integration junctions of all the transport branches for people and goods. However, in discussing selected aspects of transport in port towns it is necessary to refer to the managing of integrated transport system with taking into account its traffic safety aspects.
\end{abstract}

Keywords: boil-off gas, KC-1 membrane, LNG carrier, rigid polyurethane foam, ozone depletion potential

\section{INTRODUCTION}

Transport safety is considered a determined state of the system whose operation runs without accidents and other undesired events. The differentiation of particular transport branches ( road, railway, water and air one) as regards their organization, transport routes and means makes reaching a common managing plane difficult. But, despite the differences, philosophy of safety and the goal which is aimed at in these aspects, are invariable. Research on the state of transport safety may be reduced to the analysis of :

- risk of hazards occurring in the transport system and its surrounding,

- possible counteraction against occurrence of hazards and their consequences, to be undertaken by the transport system and external rescue systems,
- mutual relations between hazards to safety and effectiveness of counteraction and mitigation of consequences of occurred events.

Consciousness of people on hazards to health and life, associated with transport or travels, is an indispensable factor for successful actions to improve transport safety. It may be exemplified by the Integrated Transport Safety System „ZEUS" developed under supervision of Prof. R. Krystek in 2009 [14]. In the frames of the project a method for integration of transport safety managing was prepared. From the point of view of port towns which serve as integration junctions for all transport branches, a common platform for managing their safety is a crucial problem to be solved. For example, in maritime transport where safety issues undergo permanent improvements $[15,16,17,18]$, adequate procedures of action are determined and particular accidents are analyzed in detail. In case of road transport such procedures are lacking, except for 
legal proceedings (in case of occurrence of fatality or heavyinjured persons ), and no detail analyses of causes of such accidents are made and no appropriate recommendations are introduced into practice.

Another problem, characteristic for port towns where an extensive heavy traffic on some street routes occurs, is the degradation of road surface structure by overloaded lorries. The problem of overloading the lorries operating on Polish roads is serious and, in some points of observation, deals with $25 \%$ of lorries traffic stream. The dealings greatly contribute to shortening life of road surface structure and greatly influence rate and intensity of road surface failures, for this reason weight control of lorries, aimed at protection of road surface structure, is important and justified. One of the methods for such control is the preselection, i.e. weighing the lorries in motion and in consequence stopping the lorries identified to be overloaded.

\section{PROBLEM OF OVERLOADED LORRIES}

\section{ACCOMPANYING CONDITIONS}

Gdynia is a transport junction of a great importance in a European scale. Across the town two Paneuropean transport passageways go. Aircraft connections are possible through Gdańsk airport at Rębiechowo (2,46 mln passengers serviced in 2011), in the future a part of the number will be serviced by a new airport at Gdynia - Kosakowo (1,5 mln passengers per year expected till 2030).The port in Gdynia ensures sea connections with ports in Europe and worldwide. Municipal transport in Gdynia belongs to the most ecological ones in Poland and the trend will be certainly continued at least for the reason that in its neighbourhood a few research centres and universities which develop new ecological technologies, are located $[4,11,12,13]$. In Gdynia there is a network of modern trolleybuses, in a part of autobus fleet, driving engines are successively adjusted to combusting pressurized natural gas , moreover, efforts are done to make inhabitants aware of correct transport behaviour and to change their negative habits. Yearly expenditures on transport infrastructure reach about $25 \%$ of the town budget (this is the largest part of it, next to that for schools and education ). In the town new transport investment projects are permanently developed, both in the area of common transport and of individual, pedestrian and bicycle traffic, as well as transport of goods.

Total length of all the roads in Gdynia amounts to $395,1 \mathrm{~km}$ (in 2011), 5,79 km of which belongs to the national highways : DK6 - leading from Łęgowo via Gdynia up to Polish-German border in Kołbaskowo, and DK20 - connecting Gdynia with Stargard Szczeciński.

In last years were completed very important investment projects in the area of road infrastructure, that significantly improved traffic conditions in Gdynia, namely, completion of The Kwiatkowski Thoroughfare which connects Gdynia port with The Tri-city Bypass Road, the putting into operation of the Rose Road, the extension of Wiśniewski street which connects the town centre with port area, the extension of the transport junction Gdynia - St. Maximilian Hill. In 2010 the number of motor cars registered in Gdynia reached 111966 cars, that gives motorization index equal to 450 cars per 1000 inhabitants (in 2008 the index amounted to 440 cars per 1000 persons). Share of intermodal railway transport, i.e. transport of road lorries on railway lorries, continuously increases. In 2002 it amounted to $1,1 \%$ of railway transport, increased up to $1,6 \%$ in 2004 , up to $2,37 \%$, in 2011 , and in 2012 it reached $3,48 \%$. In 2010 in Gdynia , turnover of goods transported by paid-work lorries (in domestic and international traffic) reached 715 thou $t$ ( by about $15 \%$ less than in 2008).

\section{METHODS FOR DETERMINING PLACES FOR PRE-SELECTION}

In Poland heavy traffic means are classified according to three categories :

- lorries without trailer,

- articulated vehicles (lorries with trailers or semitrailers),

- autobuses.

The classification is applicable to general traffic measurements , analysis of traffic capacity and traffic modelling as well as in road surface designing. To conduct a more precise analysis of heavy traffic structure and impact of vehicles on road surface, an additional classification with respect to number and configuration of vehicle axles, may be introduced. Fig. 1 shows an example of such classification.

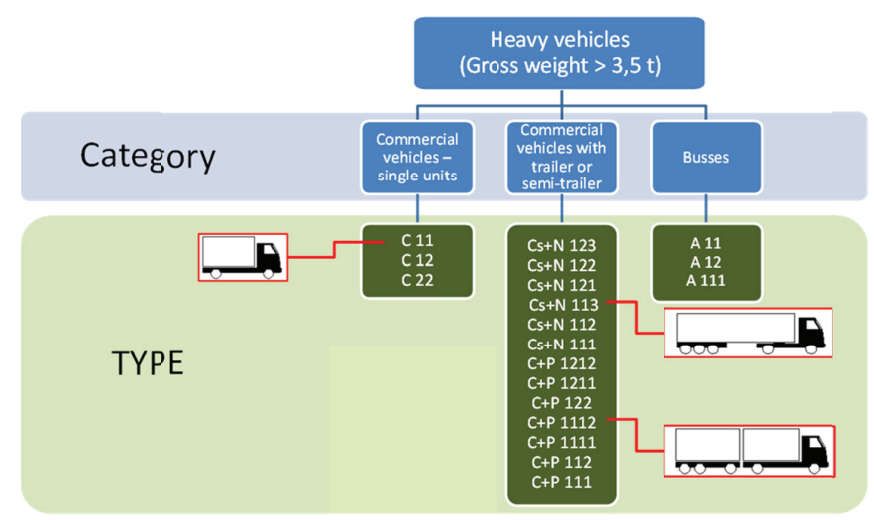

Fig. 1 Schematic diagram of classification of heavy vehicles with respect to axle configuration used in vehicle

Heavy traffic may be characterized by using mean daily traffic of heavy vehicles as well as by load (total mass) distributions and load- per- axle distributions of vehicles. The mean daily traffic of vehicles is determined individually for a given road section on the basis of traffic rate measurements. In case of determining the load distribution of vehicles to weigh the whole stream of vehicles is necessary. Execution of measurements of mass of vehicles and weights exerted on their axles requires to install special permanent devices into road surface, therefore additionally use is also made of load 
distributions taken from other roads where such measurements could be performed.

An analysis of the measurements conducted by these authors makes it possible to preliminarily estimate traffic rates and routes of heavy vehicles in Gdynia. The preliminary cartograms of heavy vehicle traffic, developed on this basis, served for formulating the concept of a system of road surface protection against destructive action of overloaded vehicles. The measurements were conducted in spring and fall of 2012 for the purposes of building the TRISTAR system. Analyzing the obtained data one may observed the highest traffic rate of heavy vehicles along The Kwiatkowski Flyover (17-23\%), where the number of heavy vehicles reaches even 8.600 units per day. In the next order, an extensive traffic of heavy vehicles was observed : along Wiśniewski street, the end fragment of the Tri-city Bypass-road as well as the exit of Morska street toward Szczecin. The traffic rates of heavy vehicles are there much lower than on The Kwiatkowski Flyover and amount to 2.300-3.200 units/day (5,8-10\%). The subsequent fragments of municipal streets located in Centrum, on which number of heavy vehicles varies about value of 1.500 units/day, are the following: Władysław IV street, Zwycięstwa avenue and the route along Wielkopolska - Chwaszczyńska streets, where the traffic rate of heavy vehicles is on the level of 3-5\%. The remaining streets are not so intensively loaded with traffic of heavy vehicles, though the rate of the traffic can reach values exceeding 500 units/day. Fig. 2 and 3 show, respectively, daily road traffic and structure of vehicle types, measured on The Kwiatkowski Flyover.

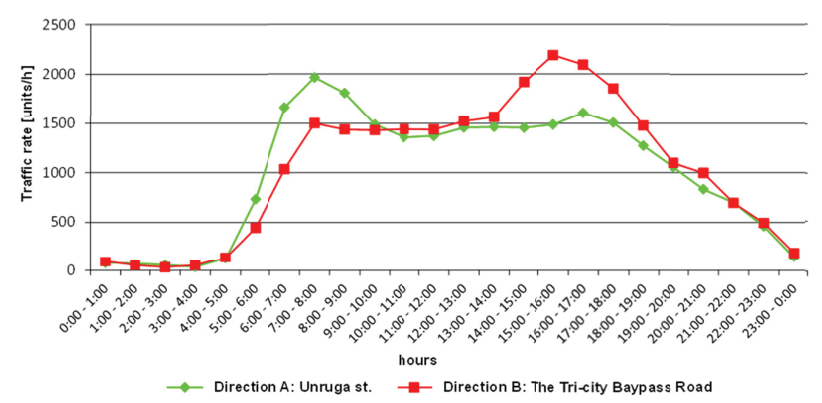

Fig. 2 Daily distribution of vehicle traffic rate measured on The Kwiatkowski Flyover, Gdynia

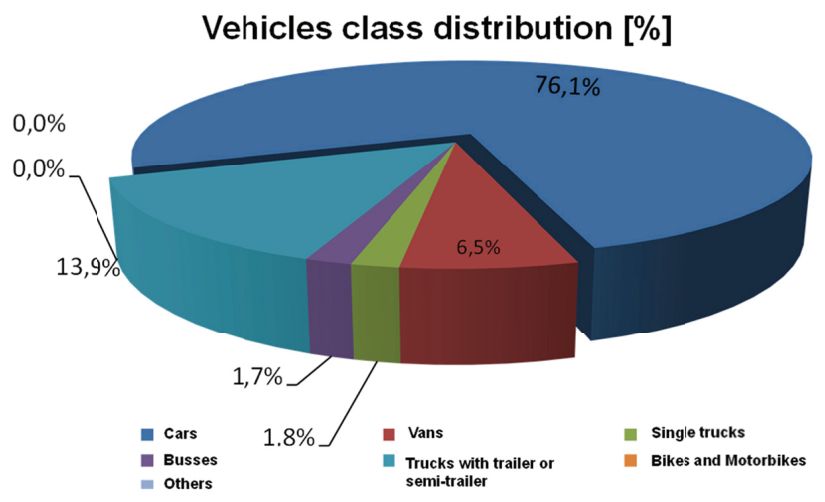

Fig. 3 Vehicles type structure observed on the Kwiatkowski Flyover, Gdynia
On the basis of the performed measurements and data obtained from in-motion-weighing (WIM) stations, the number of overloaded vehicles crossing each measurement point, was estimated. The data from the existing WIM stations provide information on the mean percentage share of overloaded vehicles for each vehicle type, separately. The mean daily number of overloaded vehicles was calculated by using the following formula :

where:

$$
L P=\sum_{i=1}^{n} U P_{i} \cdot S D R_{i}
$$

$L P$ - mean daily number of overloaded vehicles

$U P_{i}$ - mean share of overloaded vehicles of $i$-th type, calculated on the basis of the data from WIM stations,

$S D R_{i}$ - mean daily traffic rate of vehicles of $i$-th type, determined on the basis of measurements.

The traffic rate measurements were conducted between $09 \mathrm{~h}$ and $17 \mathrm{~h}$, for this reason the results were appropriately converted into daily traffic rates. Means share of overloaded vehicles for particular types of vehicles was determined on the basis of the data measured by the continuously weighing station on DK46 road at Grodziec, on a large sample of vehicles, which contain measurement results collected for two years. The problem of overloading the vehicles which operate on Polish roads is serious and leads to degradation of existing roads. According to the analyses of the data taken from WIM stations, the share of overloaded vehicles on Polish roads reaches even $25 \%$. Fig. 4 shows the share of overloaded vehicles on some domestic roads and a highway in Poland. The dealings is greatly conducive to the shortening of life of surface structure and significantly influences rate and intensity of surface structure failures, therefore it is important and justified to control load of vehicles and, consequently, to protect surface structures.

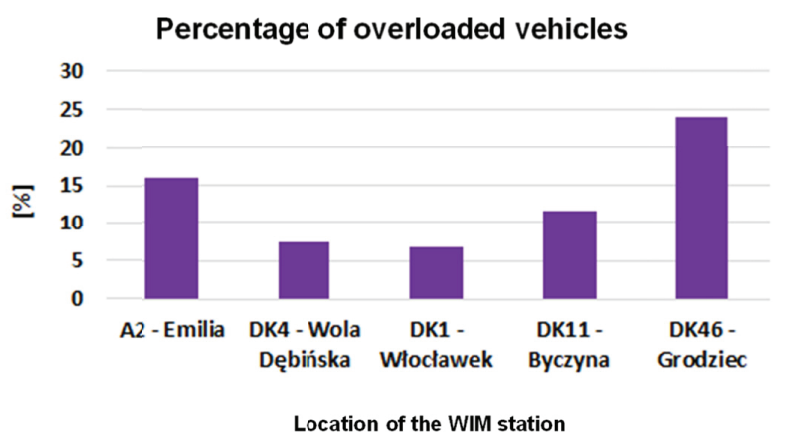

Fig. 4 Share of overloaded vehicles operating on selected roads in Poland

A legal act in force in Poland, which regulates permissible mass of vehicles and load exerted onto their axles is "The Decree of Ministry of Infrastructure on Technical Conditions of Vehicles and Scope of Their Necessary Equipment", dated December 31, 2002. The decree has been harmonized with the EU directive WD 96/53 WE. In the above mentioned regulations values of permissible mass and load per axle for various types of vehicles are described in detail. The regulations 
concerning mass and load per axle of vehicles operating on public roads are also given in Article 41 of the Act on Public Roads. According to the Act, the vehicles of the permissible load per axle of $8 \mathrm{t}$ are allowed to move over most of the roads. The Ministry of Transport is authorized to determine, by means of a decree, the list of the roads over which traffic of vehicles of load per axle of $10 t$ or $11,5 t$ is allowed. Any vehicle whose mass exceeds the limit determined in the Decree or whose load per axle for at least one component axle exceeds the limit assigned to a given road on which it moves, will be considered overloaded. In analyzing influence of overloaded vehicles on surface structure, are not taken into consideration vehicles which exceed permissible loads per axle determined by their producers, resulting from technical parameters of a given vehicle.

In respect to a way of overloading the vehicles are classified as follows :

- vehicles which exceed their permissible total mass,

- vehicles which exceed their permissible load per component axle,

- overloaded vehicles which exceed either their permissible mass or permissible load per component axle.

It should be added that in an overloaded vehicle its permissible mass and permissible load per component axle is not always exceeded simultaneously. The Tri-city agglomeration together with sea ports and many transport junctions generates traffic of a significant number of lorries. A part of them, in view of the above given comments, is potentially overloaded and causes an accelerated degradation of surface structures. For this reason implementation of a preselective weighing system for vehicles over Gdynia municipal area, is justified.

A surface structure protection system is in a sense already in operation because control of vehicles is carried out by Road Transport Inspection and Police, however its effectiveness is not sufficiently high, therefore it still requires improvement. One of the assumptions for a new surface structure protection system for Gdynia is to make use of the existing potential of equipment, technology and organization.

One of the main elements of the surface structure protection system have to be modern devices for heavy vehicles weight control as well as for traffic monitoring. As assumed in the project of the surface structure protection system for Gdynia , the stations for continuous weighing vehicles in motion (WIM - "weight in motion") will be installed as well as location points for control of vehicles by using legalized balances will be chosen.

A crucial assumption for such system is to develop a logic structure for making it possible to connect the new equipment with the existing town traffic management system TRISTAR. It is also important to ensure, for the system, continuous flow of information on potentially overloaded vehicles, from the side of vehicles' controlling services.

The choice of location points for control of vehicles as to their correct loading was conducted in three phases:

- approval of a preliminary concept,
- detail verification of the preliminary concept - acceptance of its four variants,

- selection of the target variant intended for implementation in practice.

The selection of the weight control points for vehicles in motion was based on a multi-criterion analysis in the frames of which the following was considered :

- expected effectiveness of solutions to be introduced,

- mean daily traffic rate of heavy vehicles over streets of Gdynia,

- heavy traffic structure,

- number of potentially overloaded vehicles,

- technical conditions on a road and state of its surface structure,

- grade of a road and character of traffic on it (local, transit).

Preliminary concept of layout of weight control points for vehicles

In the preliminary concept it was assumed to limit the traffic of overloaded vehicles in Gdynia as much as possible. The choice of the points in question was made on the basis of :

- traffic measurements,

- the model of heavy traffic in Gdynia , presented in Fig. 5 ,

- detail measurements concerning number of overloaded vehicles,

- assessment of state of town streets.

Based on the model, the cartogram of heavy traffic rate, shown in Fig. 5 , was produced. As can be seen in the figure, the biggest heavy traffic rate was observed on the route leading through The Tri-city Bypass Road, The Kwiatkowski Thoroughfare, The Kwiatkowski Flyover up to the container handling base ( at Kontenerowa street). A highly loaded entry to Gdynia is also Morska street at Cisowa (1800 units/day) and Hutnicza street (1200 units/day). Wiśniewski street and Polska street which lead to port, are also highly loaded by traffic. Less loaded entries to the town are Chwarznieńska street, Zwycięstwa avenue and Wiejska street (the entry from the side of Pogórze).

In the scope of the preliminary concept of the layout of weighing points the following locations have been chosen : Morska street at the boundary of Rumia - entry to Gdynia, Hutnicza street at the boundary of Rumia - entry to Gdynia, Kontenerowa street - exit from the container handling base, The Kwiatkowski Flyover, The Kwiatkowski Thoroughfare entry to Gdynia from the side of The Tri-city Bypass Road, Wiśniewski street - its section between The Ofiar Grudnia 70's Junction and Energetyków street, Chwaszczyńska street entry to Gdynia from the side of Chwaszczyno, Chwarznieńska street - entry to Gdynia , precisely its section between The Tri-city Bypass Road and Witomino, Zwycięstwa avenue entry to Gdynia from the side of Sopot, precisely its section between Kolibki and the supermarket Klif, Chwaszczyńska street, precisely its section between Nowowiczlińska street and Gryfa Pomorskiego street, Morska street, precisely its section between Obwodowa street and The Kwiatkowski Flyover, The 
Tri-city Bypass Road, precisely its section before its crossing with Morska street, Wiejska street (Pogórze), precisely its section before the traffic circle, The Tri-city Bypass Road, precisely its section between The Osowa Junction and The Chwaszczyńska Junction.

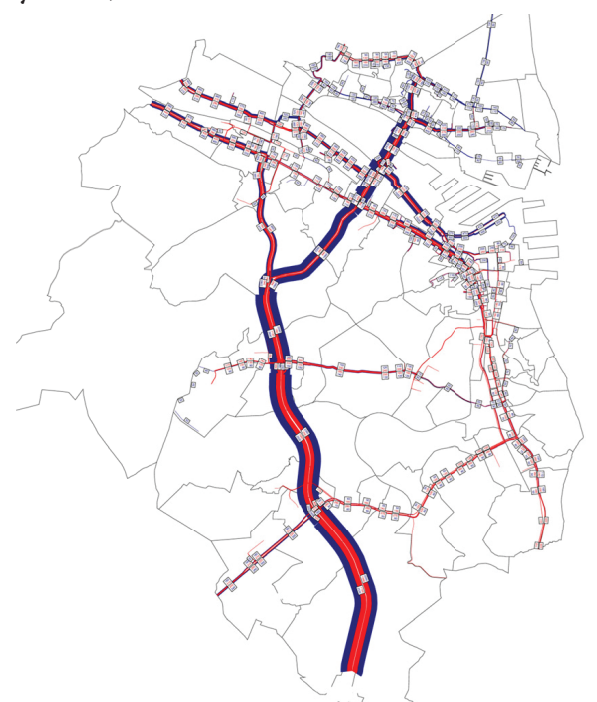

Fig. 5 Cartogram of heavy vehicles' traffic in Gdynia

Verification of the preliminarily accepted concept of layout of stations for weighing vehicles in motion

The verification has been aimed at the rejecting of such points of location in which equipment of WIM stations would not operate correctly, or their expected effectiveness in lowering the number of overloaded vehicles would be low. For verification of the preliminarily accepted points of location of WIM stations the following was taken into account:

- making use of the existing infrastructure,

- effectiveness of solutions to be implemented,

- percentage of overloaded vehicles operating on the considered roads,

- drop of the number of overloaded vehicles after putting into operation the heavy vehicles' control system,

- economic profits from the implemented solutions,

- administrative factors,

- technical factors :

- state of surface structures (load carrying capacity, evenness),

- geometric layout of a road,

- access to electricity and possibility to transfer data.

As a result, were rejected the location points for WIM stations where the assessment has revealed the following drawbacks :

- insufficient state of surface structure ( too large measurement error ),

- sections of too large longitudinal slopes or having to high bendiness,

- sections on which frequent acceleration and braking operations of vehicles may happen, i.e. those where too many crossings equipped with traffic light signalling occur,
- sections along bridge objects,

- sections not subjected to municipal administration of Gdynia. To the second phase of planning the WIM stations system, were taken into account those points of location which could bring the greatest profits. The basis for the further verification of the concept in question was a traffic analysis of overloaded vehicles within the scope of which the following was performed :

- studies of heavy traffic structure and that of overloaded vehicles on the basis of data available from continuous weighing the vehicles in motion,

- measurements of traffic structure, conducted in Gdynia,

- a detail analysis of heavy traffic structure and determination of mean daily number of overloaded vehicles operating on roads of Gdynia ,

- preparation of a traffic model of overloaded vehicles for Gdynia,

- determination of product of daily traffic of overloaded vehicles and length of their path covered along roads of Gdynia.

\section{Concept of the best solutions}

Out of the preliminarily accepted fourteen location points of WIM stations, the two were selected : at Morska street and Wiśniewskiego street, shown in Fig. 6. In these locations the possible installation of weighing stations operating in two working modes was considered, namely :

- WIM-HS stations in which measurement of vehicle mass and axle load is carried out at usual traffic speed of vehicles - such measurement is loaded by a larger error than in the case of WIM-LS balances. The WIM-HS balances are installed first of all for preselection purposes;

- WIM-LS stations in which measurement of vehicle mass and axle load is carried out at a low traffic speed $(2 \div 10$ $\mathrm{km} / \mathrm{h})$. This makes it possible to make measurements in a more exact way than in the case of WIM-HS balances, however this is connected with the necessity of directing the vehicles to control points.

It is technically possible to reach a high exactness of WIM-HS balances sufficient for unambiguous indication of vehicle overloading and automatic recognition of a overloaded vehicle and assignment of a overloading fine to it. Such solutions are more expensive than the equipment for weight preselection. Moreover there is a problem of formulating legal regulations for putting into force a system of automatic execution of fines on the basis of information from WIM-HS stations only; for this reason the reaching of full effectiveness of WIM-HS systems based on legalized measurements, may take a much longer time.

In the case of the WIM-LS balances, the carrying out of legalized control is possible if the stations are operated by appropriate services. Implementation of a legalized automatic control system into WIM-LS stations would be easier than in the case of WIM-HS stations. A drawback of WIM-LS balances is the necessity of reducing the traffic speed of vehicles. 


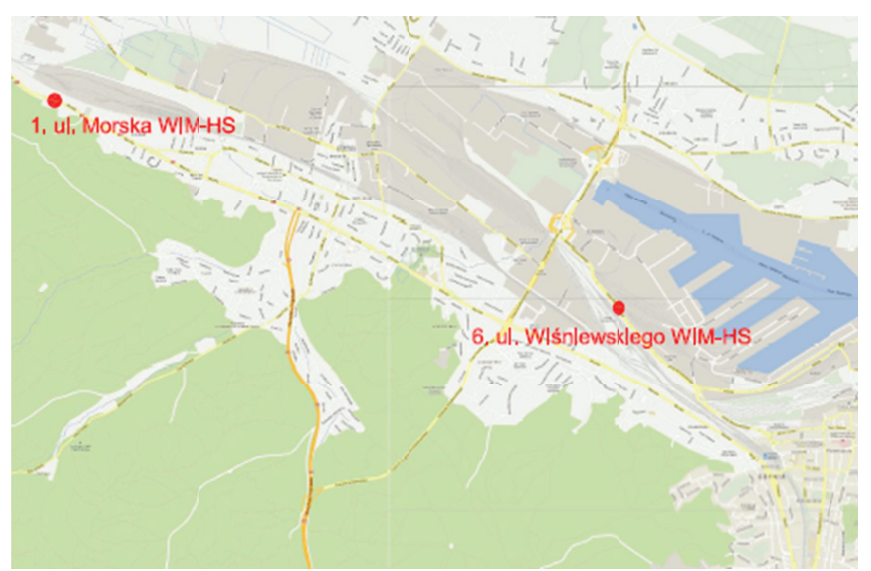

Fig. 6 Recommended location points for WIM stations

A system of preselective weighing the vehicles in motion is composed of the following elements :

- stations for preselective weighing the vehicles in motion, for both traffic directions,

- video-recording zone, for both traffic directions,

- surface structure produced with the use of asphalt technology together with substructure for traffic load of KR6 category, placed along at least $50 \mathrm{~m}$ before and $25 \mathrm{~m}$ behind the place of installation of gauges, over the full breath of traffic lane as well as full breath of roadway within the range of wearing course satisfying requirements for the measurement exactness $\mathrm{B}+(7)$ according to the specification COST 323: „Weigh in Motion of Road Vehicles”, Final Report,Appendix 1 - European WIM Specification Version 3.0, dated August 1999 ;

- internet connection allowing for real-time access to the data from preselection station by means of an internet application accessible from an arbitrary place through an internet browser, as well as allowing for transmission of data packets from a preselection station to a server;

- protection of gantry lattice columns against impact, by means of guard rails;

- protection of gantry lattice columns against possible climbing their structure by third party;

- electric supply for all the system's elements;

- design and building a road bay equipped with a weighing stand.

Additionally, implementation of GPS systems into heavy vehicles for monitoring their routes is also possible. In case of occurrence of vehicle overloading it will be easy to identify location of such vehicle [8].

\section{SELECTED PROBLEMS OF ROAD TRAFFIC SAFETY}

Crucial problems concerning the safety of road traffic participants and directions of actions necessary to improve it , have been presented on an example of the town of Gdańsk.

For five last years in the area of Gdańsk , 2861 accidents in which 3653 persons were injured including 245 seriously and 90 casualties happened. Every year about 700 persons are embroiled in traffic accidents in the town. The number of accidents and victims has showed an increasing trend in the interval from 2009 to 2012. Attention should be paid especially to increasing number of heavy injured persons by $27 \%$ in 2012 , compared with that in 2011 . However a positive trend is the decreasing number of casualties since 2011 as well as the decreasing number of accidents and victims since 2012 (Fig. 7). It shows that the direction of undertaken actions aimed at improvement of traffic safety on the roads of Gdańsk, may be deemed right.
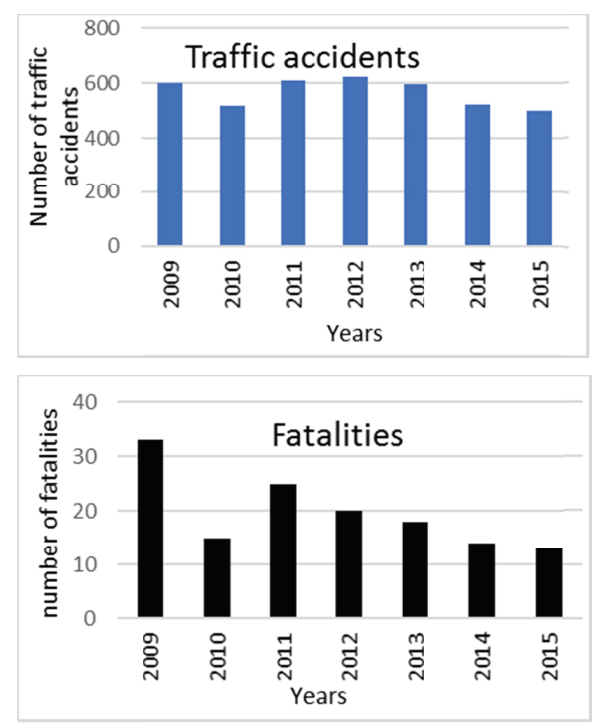

Fig. 7 Number of accidents and their victims in Gdańsk

In the base year 2013 the road traffic safety indices concerning casualties in the area of the town of Gdańsk amounted, respectively, to:

- 3,1 casualties per 100 thousand of inhabitants,

- 0,6 casualties per 10 thousand of vehicles,

- 3,1 casualties per 100 accidents,

Moreover, in 2013 it was 157,4 injured persons per 100 thousand of inhabitants.

In the years $2009 \div 2013$ in the area of the town the following accidents were most frequent :

- runs into pedestrians -954 accidents happened, i.e. 5,1\% of all accidents resulted in 61 casualties and 949 injured persons;

- side collisions between vehicles- 857 accidents happened, i.e. $41,54 \%$ of all accidents resulted in 10 casualties and 1135 injured persons;

- back collisions between vehicles - 447 accidents happened, i.e. $26,33 \%$ of all accidents resulted in 4 casualties and 666 injured persons;

- front collisions between vehicles - 274 accidents happened, i.e. $4,59 \%$ of all accidents resulted in 13 casualties and 386 injured persons. 
Pedestrians belong to a group of a very high risk. They constitute more than a half number of casualties and over $25 \%$ injured.

The analysis of safety level conducted according to streets showed that the greatest number of accidents was recorded on the following streets of Gdańsk:

- Grunwaldzka street- 213 accidents; i.e. 8,9\% of accidents in the whole town;

- Kartuska street - 103 accidents; i.e. 4,3\% of accidents in the whole town ;

- The Św. Wojciech Thoroughfare - 86 accidents; i.e. 3,6 \% of accidents in the whole town ;

- Zwycięstwa avenue - 83 accidents; i.e. 3,5\% of accidents in the whole town;

- Haller street - 70 accidents; i.e. 2,9\% of accidents in the whole town ;

- Słowacki street - 69 accidents; i.e. 2,9\% of accidents in the whole town.

Based on the identified problems and assessment of road traffic safety (RTS) in the last years, the target for the program of improving the RTS in the town has been defined. The determining of strategic target consists in searching for such values of the indices which are a resultant of expectations and possibility of their implementation. In the phase of developing The Provincial Program of RTS- „GAMBIT Pomorski”, quantitative targets for all administrative districts as well as cities were assigned, and the year of 2010 was chosen to be base one (in accordance with the assumptions for The National RTS Program ).

The strategic target of the RTS Program „GAMBIT Gdański” is in line both with The National RTS Program and The Provincial RTS Program till 2020 "GAMBIT Pomorski".

The strategic target in question consists in decreasing the mean yearly number of casualties by $50 \%$ and seriously injured in road traffic accidents by $40 \%$ up to 2020 . The assumptions can be transformed into reaching the following values (Fig. 8):

- number of casualties in road traffic accidents not greater than 11 persons up to 2020 ,

- lowering the number of seriously injured persons in road traffic accidents to less than 28 in 2020.

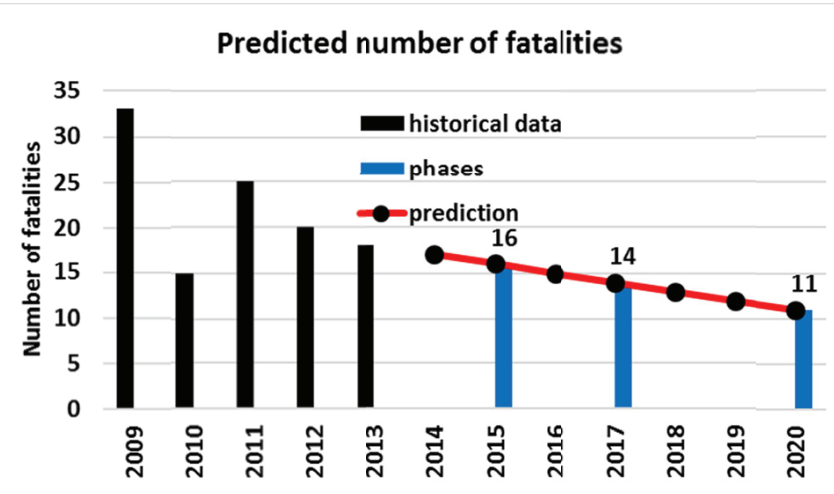

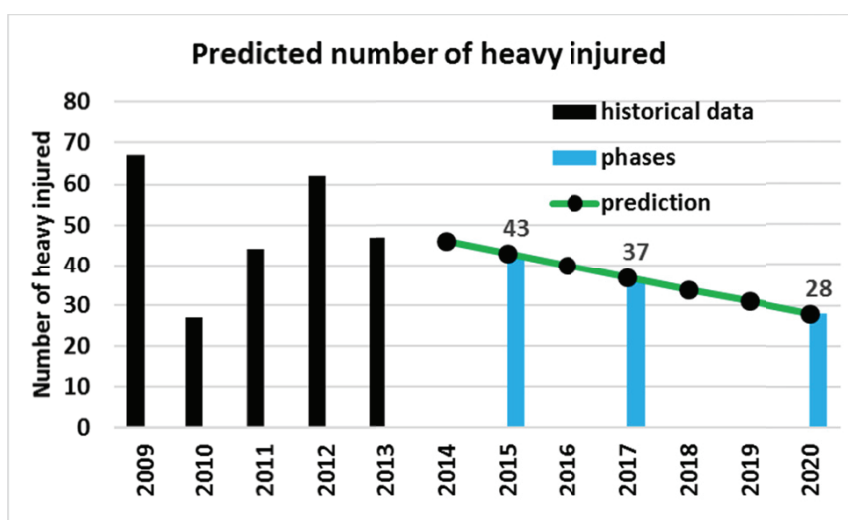

Fig. 8 Strategic target of RTS Program for Gdańsk

The following directions of undertakings necessary to be implemented, split into pillars and priorities, were prepared to reach the strategic target (Fig. 9).

\begin{tabular}{|c|c|c|c|}
\hline Pillars & \multicolumn{3}{|c|}{ Priorities } \\
\hline $\begin{array}{l}\text { System } \\
\text { operations }\end{array}$ & $\begin{array}{l}\text { Strengthening of } \\
\text { organization } \\
\text { structures }\end{array}$ & $\begin{array}{l}\text { Managing of } \\
\text { road traffic } \\
\text { safety }\end{array}$ & $\begin{array}{l}\text { Sectorial } \\
\text { operations }\end{array}$ \\
\hline Safe driver & Speed & $\begin{array}{l}\text { Safety belts and } \\
\text { other safety } \\
\text { means }\end{array}$ & $\begin{array}{l}\text { Alcohol and } \\
\text { other agents of } \\
\text { similar action }\end{array}$ \\
\hline $\begin{array}{l}\text { Safe } \\
\text { pedestrian } \\
\text { and cyclist }\end{array}$ & $\begin{array}{l}\text { Road means for } \\
\text { protection of } \\
\text { pedestrians and } \\
\text { cyclists }\end{array}$ & $\begin{array}{l}\text { Behaviour of } \\
\text { pedestrians and } \\
\text { cyclists }\end{array}$ & $\begin{array}{l}\text { Education of } \\
\text { pedestrians and } \\
\text { cyclists }\end{array}$ \\
\hline $\begin{array}{l}\text { Safe road } \\
\text { infra- } \\
\text { structure }\end{array}$ & $\begin{array}{l}\text { Safe network of } \\
\text { roads and } \\
\text { crossings }\end{array}$ & Control actions & $\begin{array}{l}\text { Modern road } \\
\text { traffic } \\
\text { management } \\
\text { systems }\end{array}$ \\
\hline Safe vehicle & Control actions & $\begin{array}{l}\text { Education and } \\
\text { promotion in the } \\
\text { area of modern } \\
\text { control } \\
\text { techniques of } \\
\text { vehicles }\end{array}$ & Supervision \\
\hline $\begin{array}{l}\text { Effective } \\
\text { system of } \\
\text { rescue and } \\
\text { post-accident } \\
\text { care }\end{array}$ & $\begin{array}{l}\text { Optimization of } \\
\text { rescue actions }\end{array}$ & First aid & $\begin{array}{l}\text { Support for } \\
\text { persons injured } \\
\text { in accidents }\end{array}$ \\
\hline
\end{tabular}

Fig. 9 Strategy of actions in the RTS Program

One of the conditions for reaching the assumed target is continuous improving the investigations in the area of 
RTS with taking into account especially control actions and developing models of influence of selected factors on RTS level, at simultaneous monitoring implemented solutions and assessing their effectiveness $[1,10,5,6,20]$.

Road network is basic element of transport system which directly impacts daily life of millions of inhabitants worldwide and economic development of countries of the world. The system contributes in social, economic and cultural development. Its great influence on life of people makes that it is considered a kind of " line of living” resulting in that the system's users expect high standards of this element of transport system.

Risk management is a process of searching for an acceptable risk level which is a balance between an ideal safety level and demands of : the system, process or service itself as well as such factors as profits for users, economic effectiveness or standards accepted by social groups. It forces , in some way, risk managing persons to define continuously a tolerated risk level, especially when social, economy and technological changes may have an influence on modification of the level [19].

In road engineering the risk management method is a repeatable and formalized way of proceeding, which connects risk assessment phase and phase of response to risk. Its task is to support managing persons in making the decisions aimed at improvement of road traffic safety as well as minimization of losses incurred by users of the transport system [9].

One of the directions of actions is safety state control over the existing network of streets. Such control consists in a periodical identification of features and faults found on an existing road, which may endanger safety of road traffic participants [2].

In the control actions, the development of tools making it possible to automate the process and improve its effectiveness, is crucial; this is possible in case of adapting solutions already implemented in other areas $[3,7]$.

\section{SUMMARY}

The above presented problems constitute only a few elements selected out of many others dealing with the transport system in port towns. Development of research methods and tools for assessing state of the system form necessary directions of further work. The indicated problems of surface structure wearing by overloaded vehicles as well as safety of road traffic participants belong to a very important part of hazards which occur in port towns. The selection of the aspects discussed in the above presented analysis was told for the reason that they have been relatively best recognized in this phase of hazards identification. The identification and counteraction against such hazards are especially important from the point of view of the correct functioning of transport system. The approved program of improvement of road traffic safety in Gdańsk should be under monitoring permanently and its effects assessed continuously. It is also necessary to especially identify hazardous spots and eliminate them by introducing the safety standards for road infrastructure.

\section{BIBLIOGRAPHY}

1. Bergel-Hayat R., Zukowska J. : Road Safety Trends at National Level in Europe: A Review of Time-series Analysis Performed during the Period 2000-12. , Transport Reviews, Vol. 35,2015 , No. 5 , pp. $650-671$

2. Budzynski M., Jamroz K., Kustra W., Michalski L.:Tools for road infrastructure safety management - Polish experiences, Transp. Res. Procedia , 2014 , 3 , pp. 730-739.

3. Burdziakowski P., Janowski A., Kholodkov A., Matysik K., Matysik M., Przyborski M., Szulwic J., Tysiąc P., Wojtowicz A.: Maritime laser scanning as the source for spatial data. Polish Maritime Research,Vol. 22, No. 4(88), (2015), pp. 9-14. http://dx.doi.org/10.1515/pomr-2015-0064

4. Cichy M, Kropiwnicki J., Kneba Z: A model of thermal energy storage according to the convention of bond graphs $(B G)$ and state equations (SE). Polish Maritime Research, Vol. 22, No.4 (88) (2015), pp. 41-47.

5. Elvik R., Vaa T.: The Handbook of Road Safety Measures, Elsevier, 2004.

6. Gaca S.: Speed tests of vehicles and its impact on road traffic safety ( in Polish ). Politechnika Krakowska ( Cracow University of Technology), 2002.

7. Janowski A., Jurkowska A., Lewczuk D., Szulwic J., Zaradny A.: Assessment of cliff stability after the demolition of the engineering facilities. $14^{\text {th }}$ International Multidisciplinary Scientific Geo-conference (SGEM) : Geo-conference on science and technologies in geology, exploration and mining, SGEM 2014, Vol. II, ISBN 978-619-7105-08-7 / ISSN 1314-2704, 2014, DOI: 10.5593/SGEM2014/B12/S2.016

8. Janowski A., Nowak A., Przyborski M., Szulwic J.: Mobile indicators in GIS and GPS positioning accuracy in cities. 2nd International Conference on Rough Sets and Emerging Intelligent Systems Paradigms (RSEISP) held as part of Joint Rough Set Symposium (JRS), 2014, Springer International

9. Jamroz K.: Risk management method in road engineering (in Polish). Politechnika Gdańska, (Gdańsk University of Technology), 2011.

10. Jamroz K., Smolarek L.: Driver fatigue and road safety on Poland's national roads. International Journal of Occupational Safety and Ergonomics, 19 , (2013) pp. 297-309.

11. Kneba Z., Kropiwnicki J.: The initial selection of parameters for dynamic brake for car engine test dynamometer. Key Engineering Materials, Vol. 597 (2014), pp. 179-184. 
12. Kropiwnicki J., Kneba Z.: Carbon dioxide potential reduction using Start-Stop system in a car. Key Engineering Materials, Vol. 597 (2014), pp. 185-192.

13. Kropiwnicki J., Kneba Z., Ziółkowski M.: Test for assessing the energy efficiency of vehicles with internal combustion engines. International Journal of Automotive Technology, Vol. 14, No. 3 (2013),pp. 479-487.

14. Krystek R.: The integrated road transport safety system ZEUS ( in Polish), WKŁ, 2009.

15. Szłapczyński R.: Evolutionary Planning of Safe Ship Tracks in Restricted Visibility. Journal of Navigation, Vol. 68, No. 01 (2015), pp.39-51

16. Szłapczyński R., Szlapczyńska J.: A Target Information Display for Visualizing Collision Avoidance Manoeuvres in Various Visibility Conditions. Journal of Navigation,Vol. 68,No. 06 (2015), pp.1041-1055

17. Szłapczyński R., Szłapczyńska J.: Customized crossover in evolutionary sets of safe ship trajectories. International Journal of Applied Mathematics and Computer Science. -Vol. 22, No.4 (2012),pp.999-1009, ISBN:978-3-319-08729-0; 978-3-319-08728-3, DOI: 10.1007/978-3-319-08729-0_31. http://link.springer. com/10.1007/978-3-319-08729-0_31

18. Szłapczyński R., Szłapczyńska J.: On evolutionary computing in multi-ship trajectory planning. Applied Intelligence ,2011, pp.1-20

19. Technical Committee 18 : Study on Risk Management for Roads, PIARC, 2004.

20. Wachnicka J., Jamroz K., Smolarek L.: Hierarchical random models in road transport safety. Safety and Reliability: Methodology and Applications, 2014, pp. 355-360.

\section{CONTACT WITH THE AUTHOR}

Marcin Budzyński

e-mail:mbudz@pg.gda.pl

Dawid Ryś

Wojciech Kustra

Gdańsk University of Technology

11/12 Narutowicza St.

80 - 233 Gdańsk

Poland 